ОСНОВНІ ПРОБЛЕМИ В РЕФОРМУВАННІ СОЦІАЛЬНОЇ СФЕРИ УКРАЇНИ

\title{
THE MAIN PROBLEMS IN THE REFORM OF THE SOCIAL SPHERE OF UKRAINE
}

Удк 351.84 : 364.442

https://doi.org/10.32843/bses.50-60

\section{Буряк І.В.}

к.е.н., викладач кафедри

державного управління,

публічного адміністрування

та регіональної економіки

Харківський національний

економічний університет

імені Семена Кузнеця

Болотова О.O.

к.е.н., викладач кафредри

державного управління,

публічного адміністрування

та регіональної економіки

Харківський національний

економічний університет

імені Семена Кузнеця

\section{Buriak Iryna}

Simon Kuznets Kharkiv National

University of Economics

Bolotova Olena

Simon Kuznets Kharkiv National

University of Economics
В роботі проведено аналіз проведення реформування в соціальній сфрері країни, а саме: в сорері надання соціальних послуг, пенсійної системи та охорони здоров'я. Розглянуто особливості проходження трансформаційних процесів в даних сфрерах в сучасних умовах. Визначено, що система соціальної сорери має не тільки позитивний результат, тому було виокремлено основні проблеми в ресрормування соціальної сорери та запропоновані шляхи вирішення їх. Акцентовано увагу на соціальних послугах й проведено аналіз відповідного законодавства України, відображено основні інноваційні засади закону «Про соціальні послуги», що вступив в дію у січні 2020 року. Наведено головні принципи нової редакції закону, а саме демонополізація ринку соціальних послуг, тобто створення умов для надання таких послуг як юридичним організаціям, так і фрізичним особам. Виокремлено етапи проведення медичної реформи та проведено аналіз розподілу видатків державного бюджету України у 2019 році.

Ключові слова: реформа, медична реформа, соціальна політика, видатки бюджету, демонополізація, соціальні послуги, охорона здоров'я, пенсійна реорорма.

B работе проведен анализ проведения ресрормирования в социальной сфрере страны, а именно: в сорере предоставления социальных услуг, пенсионной системы и здравоохранения. Рассмотрены особенности прохождения трансформационных прочессов в данных ссрерах в современных условиях. Определено, что система социальной сореры имеет не только положительный результат, поэтому было выделено основные проблемы в рефрормировании социальной сореры и предложены пути решения их. Акцентировано внимание на социальных услугах и проведен анализ соответствующего законодательства Украины, отражены основные инновационные принципы закона «О социальных услугах», который вступил в действие в январе 2020 года. Приведены основные принципы новой редакции закона, а именно демонополизация рынка социальных услуг, то есть создание условий для предоставления таких услуг как юридическим организациям, так и физическим лицам. Выделены этапы проведения медицинской реформы и проведен анализ распределения расходов государственного бюджета Украины в 2019 году.

Ключевые слова: рефрорма, медицинская реформа, социальная политика, расходы бюджета, демонополизация, социальные услуги, здравоохранение, пенсионная ресрорма.

In today's rapidly changing global challenges, on which the security of human development and social progress depend, social reform is playing an increasingly important role. Today, the country is in a rather difficult situation (conducting an anti-terrorist operation in the East, complicating economic development and growing social tensions among the population), which implies the need to implement reforms to provide social services to the population. The strategy of reforming the social services system is relevant, as not all tasks have been completed. The paper analyzes the implementation of reforms in the social sphere of the country, namely: in the field of social services, pension system and health care. Peculiarities of transformation processes in these spheres in modern conditions are considered. It is determined that the system of the social sphere has not only a positive result, so the main problems in the reform of the social sphere were identified and ways to solve them were proposed. Emphasis is placed on social services and an analysis of the relevant legislation of Ukraine is conducted, the main innovative principles of the law "On social services", which came into force in January 2020 , are reflected. The main principles of the new version of the law are given, namely the demonopolization of the market of social services, ie the creation of conditions for the provision of such services to both legal entities and individuals. The stages of medical reform are highlighted and the analysis of the distribution of expenditures of the state budget of Ukraine in 2019 is carried out. The pension reform of Ukraine was also considered, "weaknesses" were identified and ways to overcome the shortcomings were suggested. With regard to the reform of the national health care system, it is carried out in accordance with the Concept of Public Health System Development and the Action Plan for the implementation of the Concept of Public Health System Development, which is expected to be implemented in 2017-2020. Final steps are currently underway to reform health care, in particular to ensure more effective management of medical infrastructure in a decentralized environment, technical criteria have been established to define the geographical boundaries of hospital districts and the procedure for their establishment.

Key words: reform, medical reform, social policy, budget expenditures, demonopolization, social services, health care, pension reform.

Постановка проблеми. В сучасних швидко змінюваних умовах глобальних викликів, від яких $\epsilon$ залежними безпека людського розвитку та суспільний прогрес, все більшу роль відіграє соціальне ресоормування. Сьогодні країна перебуває в досить складних умовах (проведення антитерористичної операції на Сході, ускладнення економічного розвитку та зростання соціальної напруги серед населення), що передбачає необхідність впровадження перетворень 3 надання соціальних послуг населенню. Вибір пріоритетних напрямків реформування соціальної сфери вимагає використання нових перспективних методів та інструментів для досягнення позитивного результату. Саме тому в сучасних умовах $є$ необхідність про- ведення аналізу та виявлення основних проблем у сфрері соціального реформування.

Аналіз останніх досліджень і публікацій. Питання рефрормування соціальної сфери ретельно опрацьовано у роботах багатьох українських авторів, а саме: К. Дубич, А. Дутчак, Г. Лопушняк, О. Макарова, В. Скуратівський, В. Трощинський, В. Філіпчук та ін. [1-6]. Однак, необхідно підкреслити, що існуючі дослідження щодо соціального ресрормування не дають можливості системного та комплексного отримання даних та виявлення актуальних проблем у зв'язку з мінливістю розвитку соціально-економічного середовища. Тому особливої значущості набуває розгляд актуальних у сьогоденні 
проведених реформ та виявлення «слабких місць» в них.

Постановка завдання. Метою дослідження $€$ аналіз проведення реформ в соціальній сорері України в сучасних реаліях.

Виклад основного матеріалу дослідження. Відповідно до ст. 1 Конституції України [7], де проголошено, що Україна є демократичною, правовою та соціальною державою, що, таким чином, є головним підґрунтям щодо налагодження соціальноорієнтованого напрямку держави.

У Законі України «Про соціальні послуги» [8] наголошено про перехід від моделі соціального захисту, який має за основу неефективні соціальні грошові виплати, до сучасної євроінтеграційної моделі надання населенню соціальних послуг. Однак, необхідно наголосити, що основними формами соціальної політики України є соціальні виплати, пільги та соціальні послуги, що є новою фрормою соціального захисту в Україні, що не в змозі охопити одразу всі соціально не захищені верстви населення.

Система соціальних послуг в Україні починала розвиватись у 2003 році, в якому вперше ухвалено Закон «Про соціальні послуги», що є фрундаментом для створення нової галузі та визначення терміну «соціальні послуги». У 2007 році затверджено Концепцію реформування системи соціальних послуг, що мала на меті підвищення якості надання соціальних послуг й впровадження механізму управління та регулювання системою для відповіді на потреби отримувачів послуг. У 2012 році затверджено інноваційну стратегію реформування системи соціальних послуг з оновленими завданнями забезпечення доступності, якісної ефрективності необхідних послуг, у тому числі демонополізації та започаткування конкуренції серед надання соціальних послуг.
У 2019 році було запропоновано та затверджено нову редакцію Закону «Про соціальні послуги», який 31 січня 2020 року набуває чинності та перелічує такі інноваційні засади:

- конкретизація переліку соціальних послуг, учасників та етапів, що в свою чергу створює систему;

- деталізація повноважень центральних та місцевих органів влади;

- встановлення вимог щодо фрормування реєстрів надавачів та отримувачів соціальних послуг, класифрікатор послуг;

- визначення етапів організації, планування, фрінансування, впровадження та моніторингу якості надання соціальних послуг.

Для забезпечення впровадження положень нової редакції Закону «Про соціальні послуги» розроблено низку нормативних документів підзаконних акти щодо різних аспектів соціальних послуг (як організації їх надання, так і змісту послуг) включають акти КМУ, накази Мінсоцполітики та інших центральних органів влади.

Головною особливістю нової редакції Закону «Про соціальні послуги» є демонополізація ринку соціальних послуг, що дає можливість надавати такі послуги не тільки державним організація. Таким чином, в Законі наголошується, що надавачами соціальних послуг - $є$ юридичні та фрізичні особи будь-якої фрорми власності, які відповідають критеріям, що встановлені Кабінетом Міністрів України та в перспективі будуть включені у Реєстр надавачів соціальних послуг (рис. 1)

Згідно з принципами дії ринкових відносин та демонополізації соціальних послуг, всі організації, які $\epsilon$ надавачами соціальних послуг мають працювати за рівних умов, незалежно від їх фрорми власності.

Слід зазначити, що в Україні на сьогодні відсутнє ліцензування надавачів соціальних послуг,

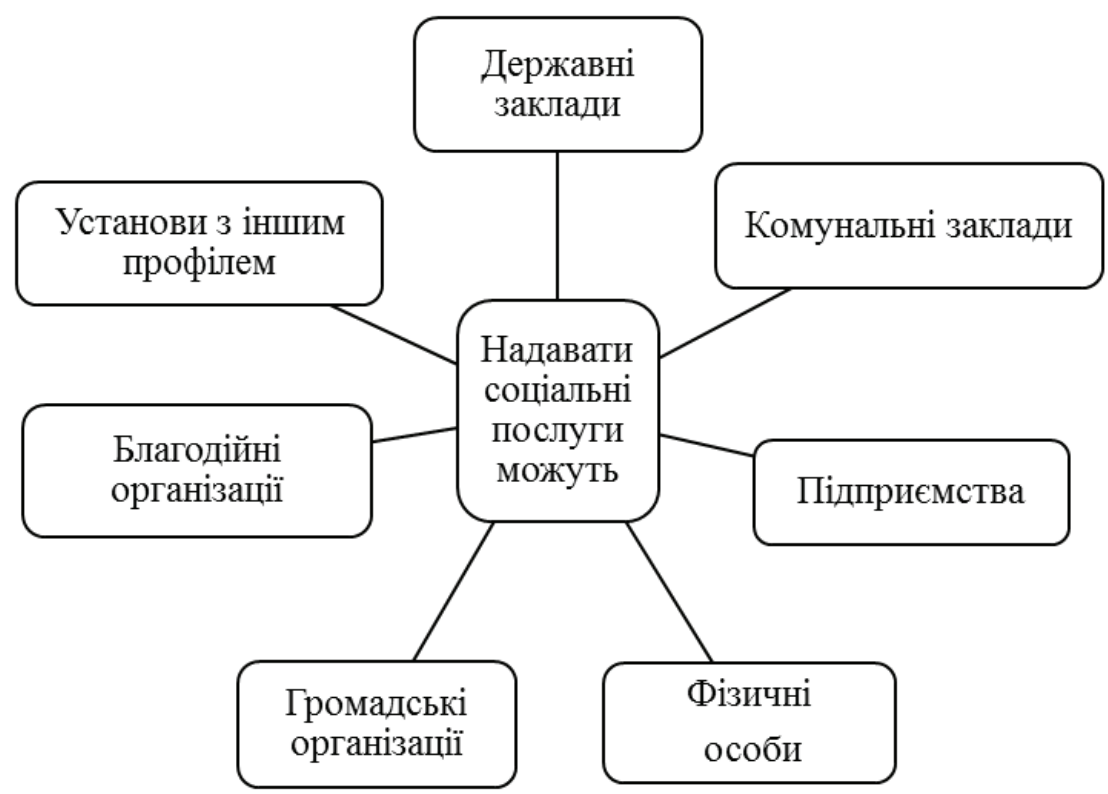

Рис. 1. Сектори надавачів соціальних послуг 
але відповідно до нового Закону «Про соціальні послуги» буде запроваджено Реєстр, який є автоматизованою системою для збору даних про суб'єкти, що надаватимуть соціальні послуги [9].

що стосується Пенсійної реформи, яка впроваджується 3 жовтня 2017 року та вдосконалює солідарну систему пенсійного страхування, звільнює її від не властивих їй видатків. Дана ініціатива передбачає такі зміни:

- збільшення нарахованої пенсії з 2021 року на коефріцієнт, який відповідає 50\% показника зростання споживчих цін за попередній рік і 50\% показника зростання середньої заробітної плати за три календарні роки, що передують року, в якому проводиться збільшення [9];

- запровадження прогресивного страхового стажу виходу на пенсію, тобто щорічно страховий стаж має зростати на один рік і до 2028 року досягнути 35 років);

- запровадження єдиних правил призначення пенсій, зокрема, щодо спеціальних пенсій і пенсій за вислугу років;

- на загальну систему нарахування пенсій переводяться працівники сфери освіти, охорони здоров'я, соціального захисту, працівники прокуратури, державні службовці, судді, вчені;

- зменшення величини оцінки одного року страхового стажу з 1,35 до 1,0;

- поновлення виплати пенсії працюючим пенсіонерам у повному обсязі, тобто скасування 15\% обмеження для пенсіонерів, які працюють, тобто передбачається, що вони зможуть одночасно отримувати і зарплату, і пенсію в повному обсязі [10].

Однак, слід зазначити, що пенсійні нововведення поки не $€$ рефрормою фрактично, оскільки лише вдосконалюють стару солідарну пенсійну систему, змінюють підходи до наповнення Пенсійного фонду. Багато положень реформи ще будуть уточнюватись і допрацьовуватися, деякі можуть бути змінені чи скасовані зовсім.

Станом на 01 січня 2020 року середній розмір пенсійних виплат становив 3083 грн, що на 437 грн більше, ніж станом на 01 січня 2019 року.

Також у 2019 році було запроваджено щорічну індексацію пенсій та продовжено поетапний перерахунок пенсій військовослужбовцям, запроваджений у 2018 році.

Аналізуючи проблеми пенсійної системи України та впровадження відповідних реформ необхідно зробити наголос на головних проблемах, такі як деоріцит бюджету (страхових коштів) Пенсійного фронду і зниження середнього коефіцієнта заміщення пенсією втраченого заробітку. Вирішення таких проблем не можливе без втручання держави, оскільки є похідними від макроекономічної та демографрічної ситуації в країні [9].

Реформа національної системи охорони здоров'я здійснюється відповідно до Концепції розвитку системи громадського здоров'я [11] та Плану Заходів щодо реалізації Концепції розвитку системи громадського здоров'я, реалізація яких передбачається упродовж 2017-2020 років.

Наразі тривають фрінальні кроки щодо реформування охорони здоров'я, зокрема з метою забезпечення більш ефективного управління медичною інфрраструктурою в умовах децентралізації встановлені технічні критерії для визначення географрічних меж госпітальних округів та порядок їх створення (передбачено наявність принаймні однієї лікарні інтенсивного лікування (першого чи другого рівня)).

19 жовтня 2017 року Верховна Рада ухвалила урядовий Закон «Про державні фрінансові гарантії надання медичних послуг та лікарських засобів» [12]. Цей акт змінює систему фрінансування охорони здоров'я та лікувально-профрілактичних закладів. Базовими положеннями медичної рефрорми в Україні є такі:

- основою державного фрінансування визначено «програму медичних гарантій», що представляє собою перелік видів послуг та обсягів медичної допомоги, а також перелік лікарських засобів, що мають надаватися на умовах повної оплати за рахунок коштів Державного бюджету України; мінімальний обсяг коштів, які спрямовуються на забезпечення державних фрінансових гарантій на медичну допомогу, становитиме 5\% ВВП; цей перелік гарантій буде щорічно встановлюватися Урядом і затверджуватися Парламентом;

- держава не виділятиме кошти на утримання медичних установ, а оплачуватиме медичні послуги за зверненням громадян, і ці гроші «будуть іти за пацієнтом»;

- сімейний лікар отримуватиме кошти в сумі 210 грн. на рік за кожну особу, з якою укладе контракт;

- медичні послуги, які фрінансуються державою, можуть надаватися недержавними медичними закладами;

- передбачено перехід до моделі закупівель медичних послуг єдиним національним замовником, а саме Національною службою охорони здоров'я, через яку держава виконуватиме фрункцію замовника медичних послуг;

- новий орган виконавчої влади, що за медичною реформою виконуватиме фрункцію оплати, контролю та вибору медичних послуг.

Рефрормування медицини та поступове впровадження державних фрінансових гарантій передбачають внесення коректив до бюджетного законодавства, зокрема передбачено надання місцевим органам влади та органам місцевого самоврядування можливості фрінансувати з власного бюджету локальні програми та забезпечувати розвиток медичних установ, що перебувають у їх власності, навіть за умови поточного фрінансування вжиття заходів $з$ Держбюджету. Також вже здійснено 
нормативно-правове нормування автономізації оперативного фрункціонування медичних закладів шляхом надання їм можливостей самостійно фрормувати та затверджувати штатні розписи, а також спрощення порядку формування кошторисів для медичних закладів.

Так, за даними Державного комітету статистики України, аналізуючи розподіл видатків зведеного державного бюджету України, варто відзначити, що бюджет України має чітку соціальну спрямованість (табл. 1).

Незважаючи на складні кризові умови в економіці, держава зберегла чітку соціально орієнтовану направленість бюджету та збільшила видатки на розвиток людського капіталу - освіту, охорону здоров'я, соціальний захист - у порівнянні з 2018 роком у розмірі від 33,4\% до 70,5\% на соціальний захист та охорону здоров'я відповідно.

Взагалі, система соціальної політики в Україні постійно перебуває в процесі оновлення та модернізації відповідно до нових потреб громадян та сучасних світових підходів у наданні соціальних послуг. Ухвалення нових редакцій Законів є ключовими, переломними кроками на шляху реформування соціальних послуг, що запустить наступні фрази удосконалення системи.

Висновки з проведеного дослідження. Стратегія реформування системи надання соціальних послуг є актуальною, оскільки не всі завдання було виконано. У зв'язку з ухваленням нової редакції Закону «Про соціальні послуги» було б доцільно розробити новий план заходів на виконання вищезазначеної стратегії.

Серед головних проблем у сорері ресрормування соціального захисту населення України, які вимагають негайного вирішення, можна виділити такі:

- високий рівень участі держави у сорері соціального захисту;

- стрімке зростання вартості послуг, які надають заклади охорони здоров'я, освіти, культури, що не відповідає їхній якості;
- неефективність бюджетного управління наявними фрінансовими ресурсами як головними розпорядниками, так і окремими соціальними установами;

- недостатність коштів для фрінансування заходів у сорері соціального захисту населення.

Для вирішення розглянутих проблем пропонуємо такий комплекс заходів:

- модернізацію системи соціального обслуговування;

- надання пільги в обсязі, достатньому для забезпечення нормальної життєдіяльності особи (сім'ї);

- розширення соціальних послуг, особливо актуальним буде створення нових для осіб, які потрапили у складну життєву ситуацію;

- сприяння розвитку молодіжних ініціатив у трудовій ссрері, перепідготовки та підвищення кваліфрікації молоді, її профрорієнтації, запобігання негативним проявам у молодіжному середовищі;

- створення правових, економічних та соціальних умов для фрунціонування і зміцнення сім'ї, поліпшення демографрічної ситуації.

Україна, прагнучи інтегруватися до європейського простору та будуючи власну стратегію розвитку, має чітко усвідомлювати як свої можливості, так і зовнішні чинники впливу. Вибір можливих альтернатив $€$ надто складним завданням, але провідною ідеєю соціально політики має залишатися прагнення до більшої справедливості суспільства та забезпечення сталого розвитку, який не погіршує умови та можливості для прийдешніх поколінь.

\section{БІБЛІОГРАФІЧНИЙ СПИСОК:}

1. Дубич К.В. Реформи соціальних послуг в Україні : сучасний стан і проблеми впровадження [Електронний ресурс]/К.В.Дубич.-Режимдоступу:http://aspect.dp.ua/ wp-content/uploads/2015/06/18-Dubych-K.V.pdf.

2. Дутчак А.В. Соціальне забезпечення громадян: сучасний стан та перспективи розвитку / А.В. Дутчак // Молодий вчений. - 2017. - № 5(45). - С. 568-572.

Розподіл видатків зведеного державного бюджету України

Таблиця 1 за фрункціональної класифікацією у 2019 році

\begin{tabular}{|l|c|c|}
\hline \multicolumn{1}{|c|}{ Статті видатків } & $\mathbf{2 0 1 9}$ рік, оракт, млрд. грн & Темпи приросту до 2018 року, \% \\
\hline Всього видатків, у тому числі: & 1075,1 & 9,1 \\
\hline Загальнодержавні фрункіії & 48,9 & 3,0 \\
\hline Обслуговування боргу & 119,2 & 3,3 \\
\hline Оборона & 106,6 & 21,8 \\
\hline Громадський порядок та судова влада & 142,4 & 13,8 \\
\hline Економічна діяльність & 72,4 & 20,5 \\
\hline Охорона навколишнього середовища & 6,3 & $-63,6$ \\
\hline ЖКГ & 0,11 & 70,5 \\
\hline Охорона здоров'я & 38,6 & 16,5 \\
\hline Освіта & 51,7 & 33,4 \\
\hline Соціальний захист та соціальне забезпечення & 218,6 & \\
\hline
\end{tabular}

Джерело [13] 
3. Лопушняк Г.С. Державна соціальна політика як передумова економічного розвитку України [Текст] : монограсрія / Г.С. Лопушняк. Львів : ЛРІДУ НАДУ, 2011. - 372 с.

4. Макарова О.В. Соціальна політика в Україні: Монографрія / О.В. Макарова ; Ін-т демограсрії та соціальних досліджень ім. М.В. Птухи НАН України. К., 2015. - 244 c.

5. Реформування соціальної політики в Україні: проблеми та перспективи : навч.-наук. вид. / авт. кол. : В.А. Скуратівський, В.П. Трощинський, П.К. Ситник та ін. ; за заг. ред. В.А. Скуратівського, В.П. Трощинського. - К.; Львів : НАДУ, 2012. - 368 с.

6. Філіпчук В.Р. Порівняльний аналіз української та європейської систем соціального захисту населення / В.P. Філіпчук // Вісник Хмельницького національного університету. - 2014. - № 5. - Т. 1. - С. 195-198.

7. Конституція України : прийнята на п'ятій сесії Верховної Ради України 28 червня 1996 року [Електронний ресурс] - Режим доступу: http://zakon3.rada.gov.ua/ laws/show/254k/96-вр.

8. Про схвалення Стратегії рефрормування системи надання соціальних послуг : [Розпорядження Кабінету Міністрів України від 8 серп. 2012 р. № 556-р.] // Офріц. вісн. України. - 2012. - 20 серп. (№ 61). - С. 71. - Ст. 2482.

9. Щодо вдосконалення пенсійного законодавства в Україні. Аналітична записка Національний інститут стратегічних досліджень [Електронний ресурс]. Режим доступу: http://www.niss.gov.ua/ articles/1830.

10. Пенсійна реформа [Електронний ресурс]. Режим доступу: https://product.ligazakon.ua/pensionn.

11. Про схвалення Концепції розвитку системи громадського здоров'я [Електронний ресурс]. - Режим доступу: https://www.kmu.gov.ua/npas/249618799.

12. Про державні фрінансові гарантії медичного обслуговування населення [Електронний ресурс]. - Режим доступу: https://zakon.rada.gov.ua/ laws/show/2168-19.

13. Інформація Міністерства ффінансів України про виконання Державного бюджету України за 2019 рік [Електронний ресурс]. - Режим доступу: https:// ukurier.gov.ua/uk/articles/informaciya-ministerstvafinansiv-ukrayini-pro-vik.

\section{REFERENCES:}

1. Dubich K.V. Reformi social'nih poslug $v$ Ukrayini : suchasnij stan i problemi vprovadzhennya [Elektronnij resurs] / K.V. Dubich. - Rezhim dostupu : http://aspect.dp.ua/wp-content/uploads/2015/06/18Dubych-K.V.pdf.

2. DutchakA.V. Social'ne zabezpechennya gromadyan: suchasnij stan ta perspektivi rozvitku / A.V. Dutchak // Molodij vchenij. - 2017. - № 5(45). - S. 568-572.

3. Lopushnyak G.S. Derzhavna social'na politika yak peredumova ekonomichnogo rozvitku Ukraïni [Tekst] : monografiya / G.S. Lopushnyak. - L'viv : LRIDU NADU, 2011. - 372 s.

4. Makarova O.V. Social'na politika v Ukraïni: Monografiya / O.V. Makarova ; In-t demografiï ta social'nih doslidzhen' im. M.V. Ptuhi NAN Ukraïni. - K., 2015. - 244 s.

5. Reformuvannya social'noï politiki v Ukraïni: problemi ta perspektivi : navch.- nauk. vid. / avt. kol. : V.A. Skurativs'kij, V.P. Troshchins'kij, P.K. Sitnik ta in. ; za zag. red. V.A. Skurativs'kogo, V.P. Troshchins'kogo. K.; L'viv : NADU, 2012. - $368 \mathrm{~s}$.

6. Filipchuk V.R. Porivnyal'nij analiz ukraïns'koï ta €vropejs'koï sistem social'nogo zahistu naselennya / V.R. Filipchuk // Visnik Hmel'nic'kogo nacional'nogo universitetu. - 2014. - № 5. - T. 1. - S. 195-198.

7. Konstituciya Ukraïni : prijnyata na p'yatij sesiï Verhovnoï Radi Ukraïni 28 chervnya 1996 roku [Elektronnij resurs] - Rezhim dostupu: http://zakon3.rada.gov.ua/ laws/show/254k/96-vr

8. Pro skhvalennya Strategiï reformuvannya sistemi nadannya social'nih poslug : [Rozporyadzhennya Kabinetu Ministriv Ukraïni vid 8 serp. 2012 r. № 556-r.] // Ofic. visn. Ukraïni. - 2012. - 20 serp. (№ 61). - S. 71. St. 2482.

9. SHCHodo vdoskonalennya pensijnogo zakonodavstva v Ukraïni. Analitichna zapiska Nacional'nij institut strategichnih doslidzhen' [Elektronnij resurs]. Rezhim dostupu: http://www.niss.gov.ua/ articles/1830.

10. Pensijna reforma [Elektronnij resurs]. - Rezhim dostupu: https://product.ligazakon.ua/pensionn.

11. Pro skhvalennya Koncepciï rozvitku sistemi gromads'kogo zdorov'ya [Elektronnij resurs]. - Rezhim dostupu: https://www.kmu.gov.ua/npas/249618799.

12. Pro derzhavni finansovi garantiï medichnogo obslugovuvannya naselennya [Elektronnij resurs]. - Rezhim dostupu: https://zakon.rada.gov.ual laws/show/2168-19.

13. Informaciya Ministerstva finansiv Ukraïni pro vikonannya Derzhavnogo byudzhetu Ukraïni za 2019 rik [Elektronnij resurs]. - Rezhim dostupu: https://ukurier.gov.ua/uk/articles/informaciya-ministerstva-finansiv-ukrayini-pro-vik. 